\title{
IRENA ŁADOSIÓWNA - AKTORKA POLSKIEGO TEATRU W STANISŁAWOWIE I DZIENNIKARKA „KURIERA STANISŁAWOWSKIEGO” (1933-1936)
}

\author{
Olga Ciwkacz \\ Towarzystwo Kultury Polskiej im. Fr. Karpińskiego w Iwano-Frankiwsku \\ ORCID: 0000-0002-8764-5420
}

\begin{abstract}
Streszczenie. Artykuł poświęcony jest działalności artystycznej Ireny Ładosiówny, aktorki i reżyserki, podczas jej pracy na scenie Polskiego Teatru im. Stanisława Moniuszki w Stanisławowie w latach 1933-1937, gdzie odnosiła duże sukcesy zarówno jako odtwórczyni różnorodnych ról scenicznych, jak też reżyser odpowiedzialny za koncepcję oraz przygotowanie całości spektaklu. Ponadto Ładosiówna prezentowana jest jako felietonistka „Kuriera Stanisławowskiego”. Podstawowym źródłem informacji pozostają artykuły prasowe dotyczące działalności stanisławowskiego teatru oraz felietony autorstwa Ładosiówny z lat 1933-1936.
\end{abstract}

Slowa kluczowe: Irena Ładosiówna, teatr, aktorka, reżyser, dziennikarka

Władze miejskie miasta Stanisławowa w roku 1933 postanowiły sprowadzić ze Lwowa zespół zawodowych aktorów pod dyrekcją Zuzanny Łozińskiej, „która prócz wybitnego talentu, wnosi do teatru młodzieńczy zapał przy wielkim doświadczeniu i gruntownej znajomości teatru", jak pisał o niej Leon Ziobrowski ${ }^{1}$. Nowo zorganizowany teatr od września 1933 roku otrzymał nazwę Teatr im. St. Moniuszki pod dyrekcją Zuzanny Łozińskiej, a jako zespół dający przedstawienia na terenie województwa stanisławowskiego - Wojewódzki Teatr Objazdowy im. St. Moniuszki². Gdy poszerzył się teren występów o miejscowości województwa tarnopolskiego, nazwa teatru zmieniła się na Teatr Pokucko-Podolski, co nastąpiło w 1935 roku. W końcu, gdy teatr objął swą działalnością tereny kilku południowych województw, przybrał nazwę Teatru Małopolskiego. W skład nowopowstałego w 1933 roku zespołu teatralnego wchodzili: dyrektor artystyczny Zuzanna Łozińska, dyrektor administracyjny Stanisław Faliszewski, reżyser i aktor Ryszard Wasilewski, zawodowi

1 L. Ziobrowski, Stały zawodowy teatr w Stanisławowie, „Kurier Stanisławowski” 1933, nr 818, 6 VIII, s. 2.

2 Archiwum, Iwano-Frankiwsk, f. 2, op. 1, spr. 1249, s. 3. 
aktorzy: Franciszek Bay-Rydzewski, Halina Dąbrowska, Wiktor Domański, Elżbieta Elwakowska, Maria Kopaczówna, Irena Ładosiówna, Stanisław Posiadłowski, Maria Sieniawska, Helena Wostrowska oraz Wacław Zabielski.

Irena Ładosiówna urodziła się 1905 roku w Lublinie, była córką Czesława Ładosia, który jako aktor był znany pod nazwiskiem Wiśniewski, oraz aktorki Jadwigi Marii Wiśniewskiej. Od najmłodszych lat była obyta ze sceną, gdyż statystowała zawsze wtedy, kiedy na scenie potrzebne było dziecko. Ponadto uczyła się w szkole baletowej i występowała jako tancerka. Po ukończeniu w 1919 roku kursów scenicznych Henryka Cepnika zadebiutowała w Teatrze Miejskim we Lwowie, gdzie grała do 1930 roku. Równocześnie kontynuowała naukę w Seminarium nauczycielskim, w którym jako eksternistka zdała maturę w 1926 roku. Rozpoczęła wówczas również działalność literacką i dziennikarską, publikując w prasie felietony i nowele. Jest autorką powieści o tematyce teatralno-filmowej Otylia Sewera, wydanej w 1930 roku w Złoczowie. W 1931 roku „Kurier Lwowski” drukował w odcinkach jej powieść Miłość wśród maków ${ }^{3}$. W latach 1930-1933 grała w sztukach teatralnych w Poznaniu, Płocku oraz Wilnie.

W latach 1933-1937 Ładosiówna była aktorką i reżyserem teatru stanisławowskiego, w którym wystawiano jej sztuki: Królowa śniegu według baśni Hansa Christiana Andersena (5 XII 1933) oraz inscenizację poematu Adama Mickiewicza Pan Tadeusz w 20 obrazach (18 III 1934). Królewnę z Lisieux, misterium religijne w 9 obrazach na podstawie życia św. Teresy od Dzieciątka Jezus (21 III 1936), Ładosiówna wyreżyserowała sama i uzyskała pochwalną opinię krytyka „Kuriera Stanisławowskiego”: „,prapremiera misterium religijnego Ireny Ładosiówny, a zarazem debiut autorski tej artystki, wypadły pod każdym wzgledem udatnie""4.

W stanisławowskim teatrze Ładosiówna pełniła obowiązki aktorki i reżysera od września 1933 do końca 1937 roku, a w 1938 przyjeżdżała do Stanisławowa na występy gościnne. W sezonie 1933/1934 grała w sztukach: Leopolda Staffa Potudnica ${ }^{5}$, komedii Paula Armonta i Marcelego Gerbidona Szkoła kokot ${ }^{6}$, Mariana Hemara Artyści ${ }^{7}$, Józefa Mazura Ułani ks. Jó$z e f a^{8}$ oraz w dramacie Mickiewicza Dziady"'. W komedii Mademoiselle Jacques'a Devala kreowała rolę tytułową ${ }^{10}$, ponadto występowała w sztuce

I. Ładosiówna, Miłość wśród maków, „Kurier Lwowski” 1931, nr 259-261, 264-268, 271275, 278-282, 285-289, 293, 295-296, 299-302, 306-307, 309-310, 314-317, 320-324, 327-331.

Teatr, „Kurier Stanisławowski” 1937, nr 14, 5 IV, s. 4.

Teatr, „Kurier Stanisławowski” 1933, nr 830, 18 X, s. 2.

Teatr, „Kurier Stanislawowski” 1933, nr 832, 25 X, s. 30.

Teatr, „Kurier Stanisławowski” 1934, nr 834, 1 XI, s. 3.

Teatr, „Kurier Stanisławowski” 1934, nr 836, 12 XI, s. 3.

Teatr, „Kurier Stanisławowski” 1934, nr 842, 29 XI, s. 4.

Teatr, „Kurier Stanisławowski” 1934, nr 845, 10 XII, s. 4. 
Piorun z jasnego nieba Stefana Kiedrzyńskiego ${ }^{11}$ i w komedii Jimm i Jill Clifforda Greya ${ }^{12}$.

W noc sylwestrową zespół Teatru pod dyrekcją Łozińskiej bawił publiczność Stanisławowa komedią Awantura w raju Franca Bacha - wielką rewią z udziałem całego zespołu teatralnego, członków Towarzystwa Muzycznego im. Moniuszki, orkiestry, baletu, rewelersów; występował też znakomity humorysta Eustachy Odrobiński ${ }^{13}$. Irena Ładosiówna grała swoją rolę dobrze, co odnotowano w prasie: „,wymienić się musi p. Ładosiównę, która stworzyła zachwycającą posłankę Karczową"14. W styczniu 1934 roku publiczność stanisławowska była zachwycona komedią Za oceanem, ktorą reżyserowała Ładosiówna, jednocześnie grająca w przedstawieniu rolę chorej koleżanki:

Niezrównaną jak zwykle była p. Łozińska grając, tańcząc, i śpiewając, zmuszano ją też do powtarzania każdego numeru, a kto nie widział jej „,matelota” i nie słyszał ballady o Don Juanie, naprawdę żałować może i powinien pospieszyć błąd naprawić. Godnie jej sekundowała w pas des trois p. Ładosiówna, która występując w zastępstwie chorej p. Dobrowolskiej, okazała, że jest równie wyborną tancerką, jak doskonałą aktorką. W jej ręku spoczywała zresztą reżyseria i ta wywiązała się bez zarzutu z zadania ${ }^{15}$.

Już 15 lutego 1934 roku odbyła się uroczysta premiera arcydzieła Juliusza Słowackiego, Lilli Wenedy, w reżyserii i inscenizacji Wasilewskiego. Rolę tytułową grała Łozińska, rolę Rozy Wenedy - Ładosiówna, Gwinony - Kopaczówna, Derwida - Bay-Rydzewski, dalszą obsadę zapewnił zaś cały zespół artystyczny oraz 30 osób personelu pomocniczego. W prasie chwalono sztukę oraz grę aktorek obsadzających główne role:

Wystawiono je z podziwu godnym pietyzmem, słuchało się też ze wzruszeniem, żaden fałszywy ton, żadne niedociągnięcie nie mąciło estetycznej całości wykonania, [...] na pierwszy plan wysunęła się Roza Weneda, z której p. Ładosiówna po mistrzowsku wydobyła akcent mocy i złowrogiej poezji. [...] Jako Lilla Weneda p. Łozińska zaimponowała wszechstronnością swego talentu... jako Lilla miała ciepło, szlachetność i urok dziewczęcy, wiersz Słowackiego brzmiał w jej ustach $\mathrm{z}$ kryształową czystością, [...] wystawa była pod każdym względem wzorowa ${ }^{16}$.

Inne walory aktorskiej gry Ładosiówny zobaczyła publiczność stanisławowska w komediofarsie Wincentego Rapackiego Papa się żeni, na co wskazuje autor recenzujący przedstawienie:

11 Kronika, „Kurier Stanisławowski” 1934, nr 870, 11 XII, s. 3.

12 Teatr, „Kurier Stanisławowski” 1934, nr 846, 20 XII, s. 2

13 Kronika, „Kurier Stanisławowski” 1934, nr 850, 31 XII, s. 3.

14 Kronika, Kurier Stanisławowski" 1934, nr 852, 7 I, s. 3.

15 Teatr, „Kurier Stanisławowski” 1934, nr 852, 7 I, s. 3.

16 Teatr, „Kurier Stanisławowski” 1934, nr 866, 25 II, s. 5. 
Zagrano [...] wesoło, ukazując szeregi doskonałych typów i dając w rezultacie bardzo miły wieczór. Znakomitą, pełną temperamentu primadonną była p. Ładosiówna, która zapomniawszy o trupio-kulinarnych eksperymentach Rozy Wenedy, z niewyczerpanym humorem bawiła cały wieczór publiczność ${ }^{17}$.

24 marca 1934 roku odbyło się specjalne przedstawienie Mickiewiczowskiego Pana Tadeusza dla młodzieży szkolnej ${ }^{18}$, w którym Ładosiówna zagrała rolę Telimeny. W „Kurierze Stanisławowskim” pisano wówczas o aktorce:

$\mathrm{Z}$ pomiędzy postaci poematu bezsprzecznie na pierwszy plan wysunęła się ciocia Telimena w interpretacji p. Ładosiówny, która ... i w interpretacji układu widowiska miała wybitny udział, a tylko przez skromnośc go ukryła; jako Telimena miała tyle stylowego wdzięku i wczucia się w intencję poety, że kreację tę śmiało między swoje czołowe zaliczyć może ${ }^{19}$.

Cztery dni później, 28 marca, odbyła się premiera sztuki Klabunda (Li-King-Tao) Kredowe koło ${ }^{20}$. Irena Ładosiówna, jednocześnie reżyserująca sztukę i grająca w niej jedną z ról, wydrukowała w „Kurierze Stanisławowskim" szkic, w którym opisała w żartobliwym tonie proces pracy nad przygotowaniem tej chińskiej bajki, pełnej egzotyki, sentymentu, tragicznych i wstrząsających scen, najzabawniejszego humoru, pięknych pieśni oraz ślicznego tańca. Wszystko według jej zamysłu miało być spowite szczególną atmosferą, którą miały tworzyć gałęzie kwitnących na różowo wiśni. Aktorka z humorem opisała przezwyciężanie trudności związanych z tym, że przedstawienie odbywało się w porze, w której trudno było o kwitnące wiśnie:

Reżyser wpadł jak bomba do kancelarii dyrektora teatru i już od progu wołał gorączkowym głosem, człowieka opętanego jakąś idée fixe. - Ziuziu! (dyrektor był kobietą). Muszę koniecznie mieć dwie kwitnące wiśnie, w drugim akcie, na scenie! - Dyrektor wzruszył pogardliwie ramionami: - Skąd ci wezmę kwitnące wiśnie, kiedy jeszcze nie kwitną [...] - Zresztą jak tak chcesz koniecznie, to wyszukaj gdzieś jaką kwiaciarkę i niech zrobi ze dwa krzaczki. Reżyser się zaperzył jak indyczka: - „Łe-tam!” (nałogowy okrzyk reżysera w chwilach silnych wzruszeń). Kto ci zrobi 2000 kwiatków w ciągu dwu dni? Naraz stuknął się pięścią w twardą i nieco skołtunioną głowę, dając sobie momentalną odpowiedź: - Już wiem - Malinka i ja zrobimy przez dzisiejszą noc! (,Malinka"21 - to imię na prywatny użytek ,„pierwszej naiwnej” teatru, o którym mowa ${ }^{22}$.

Teatr, „Kurier Stanisławowski” 1934, nr 867, 25 II, s. 3.

Ibidem, s. 2.

Teatr, „Kurier Stanisławowski” 1934, nr 873, 21 III, s. 3.

„,Kredowe koło” Klabunda, „Kurier Stanisławowski” 1934, nr 875, 28 III, s. 3.

„Malinka” - Maria Kopaczówna.

I. Ładosiówna, O brzozach, na których zakwitty wiśnie. Moim kochanym Pomocnikom, na pamiatke premiery „Kredowego Koła”, „Kurier Stanisławowski” 1934, nr 876, 1 IV, s. 4-5. 
Cały zespół ciężko pracował, aby zrobić kwiaty na czas i udekorować nimi scenę:

Komenderujące: „Malinka” i „reżyser” z wypiekami na twarzach, biegają to tu, to tam, robiąc wszystko na raz i radośnie patrzą co chwilę na rosnące stosy kwiecia... sto... dwieście... trzysta!.. z godziny na godzinę różowieją drzewa... wkrótce już trudno zliczyć drobne główki, okrywające gęsto gałęzie [...] wiśnie kwitną na leśnych brzózkach coraz piękniej [...] już dawno po północy i choć niejedno oko przymyka się sennie - wszystko głupstwo - wiśnie na premierę muszą być!23

W taki sposób kwiaty z bibułki stały się ważnym elementem scenografii Kredowego koła, które cieszyło się wielkim powodzeniem: „Całość była przedsięwzięciem, które stanowić będzie w tegorocznym sezonie jedną z pozycji najlepiej świadczących o naszym teatrze i jego kierownictwie. Zapisze to na swoje konto przede wszystkim p. Ładosiówna"24 komentował J.Z., recenzent teatralny „Kuriera Stanisławowskiego”.

Irena Ładosiówna brała udział w kolejnych przedstawieniach Teatru im. Stanisława Moniuszki w Stanisławowie: Kobieta, wino, dancing Stefana Kiedrzyńskiego ${ }^{25}$, Stawiski. Monsieur Sasza Aleksander - reportaż w 3 aktach nieznanego autora ${ }^{26}$ oraz Maurice'a Hennequina Florette i Patapon ${ }^{27}$; aktorka grała rownież w melodramacie Gabrieli Zapolskiej Moralność pani Dulskiej, wcielając się w postać Czesi, a poźniej pani Juliasiewiczowej. O przedstawieniu pisano w prasie, że

odpowiadało wartości utworu. Panie Łozińska i Ładosiówna, jako że są rodowitymi lwowiankami, grały z całą znajomością nie tylko swego talentu scenicznego, ale także i atmosfery obyczajowo-kulturalnej ówczesnego Lwowa, stąd też skupiły na swej wspaniałej grze uwagę widowni ${ }^{28}$.

W 1934 roku Ładosiówna, poza zwykłą pracą w teatrze, prowadziła kurs gry scenicznej przy konserwatorium Towarzystwa Muzycznego im. Moniuszki" "29. Po zakończeniu sezonu w Stanisławowie Teatr im. Moniuszki zaczął działalność objazdową i odwiedził pięć miast województw stanisławowskiego i tarnopolskiego, gdzie dał w sumie 17 przedstawień. O jednym z wyjazdów - do Borszczowa i Czortkowa z komedią Kiedrzyńskiego Wino,

23 Ibidem, s. 5.

24 J.Z., „Kredowe koło” Klabunda, „Kurier Stanisławowski” 1934, nr 877, 4 IV, s. 4.

25 Teatr, „Kurier Stanisławowski” 1934, nr 878, 14 IV, s. 3.

26 „Kurier Stanisławowski” relacjonował: „Z zespołu grali najlepiej jak zwykle panie Łoziń-

ska i Ładosiówna”. Zob. Teatr, „Kurier Stanisławowski” 1934, nr 885, 6 V, s. 3.

27 Teatr, „Kurier Stanisławowski” 1934, nr 891, 30 V, s. 3.

28 Teatr, „Kurier Stanisławowski” 1934, nr 892, 31 V, s. 4.

29 Teatr, „Kurier Stanisławowski” 1934, nr 937, 7 XI, s. 2. 
kobieta, dancing - Ładosiówna pisała w swoim szkicu z podróży. Przyjazd teatru był niecodziennym wydarzeniem w życiu mieszkańców małych miasteczek, w Borszczowie przygotowano nawet, wszakże trochę zaskakujący, afisz. Z humorem pisała o nim Ładosiówna: „Afisz wygląda imponująco, bo przez nieuwagę naklejacza brzmi następująco: (wielkimi literami): «Wino dancing»-(potem małymi): «początek o godz. 8-mej wiecz.»i nazwiska osób - (i znowu litery wielkie): «Kobieta»"!30.

Sala była szczelnie wypełniona publicznością. Po przedstawieniu aktorzy zostali zaproszeni na bankiet, a potem odpoczywali w wynajętych dla nich pokojach:

Nazajutrz była i serenada pod oknami i świetne śniadanie - piosenki solowe i chóralne - róże - róże - róże i obiad w jakimś pałacyku, posiadającym obserwatorium astronomiczne, świetne pianino, komiczne kaktusy, dobra kucharka i dużo fantazji, wszystko zakropione alkoholem i rzęsistym deszczem, płaczącego za nami Borszczowa. [...] Odjeżdżamy z ciepłą wdzięcznością dla całego miasteczka w ogólności i z żywymi uczuciami dla garstki teatralnych Przyjaciół, którzy nas tak przemile podejmowali ${ }^{31}$.

Drugi sezon zawodowego Teatru im. St. Moniuszki w Stanisławowie pod dyrekcją Łozińskiej zainaugurowało 7 września 1934 roku przedstawienie komedii Klub kawalerów Michała Bałuckiego. Irena Ładosiówna brała udział w spektaklu jako aktorka, podobnie jak w innych przedstawieniach tego sezonu. Grała w komediach Pieniadz to nie wszystko László Bús-Feketego i Nieuchwytny Edgara Wallace'a ${ }^{32}$. O jej roli w pierwszej z wymienionych sztuk napisano: „Najlepiej grała p. Ładosiówna, która dała nam kapitalny typ specjalistki od garnków i rondli, zręcznie i ofiarnie podsuwającej odgrzewane sznycle głodomorowi z doktorskim tytułem"33. W recenzji z przedstawienia baśni dramatycznej Lucjana Rydla Zaczarowane Kolo pisano, że z „,wykonawców najładniej $[\ldots]$ przemawiała p. Ładosiówna, której wielki talent artystyczny świecił naprawdę pełny triumf, zwłaszcza w dramatycznej scenie ostatniego aktu"34. W komedii Lakotosza Męzczyźni i kobieta ${ }^{35}$ aktorka kreowała główną rolę. O wystawieniu Towarzysza Devala krytyk pisał: „znowu podbiła bezapelacyjnie publiczność p. Ładosiówna, której gra była prawdziwym koncertem mistrzowskim, nagradzanym zasłużenie raz po raz hucznymi oklaskami”"36.

\footnotetext{
30 I. Ładosiówna, ,Wino - dancing” - początek o ósmej godzinie - $i$ „,Kobieta” $-w$ Borszczowie, „Kurier Stanisławowski” 1934, nr 896, 17 VI, s. 2.

Teatr, „Kurier Stanisławowski” 1934, nr 915, 5 IX, s. 3.

Teatr, „Kurier Stanisławowski” 1934, nr 931, 17 X, s. 4.

Teatr, „Kurier Stanisławowski” 1934, nr 923, 19 IX, s. 4.

Teatr, „Kurier Stanisławowski” 1934, nr 933, 24 X, s. 3.

Teatr, „Kurier Stanisławowski” 1934, nr 938, 11 XI, s. 5.

Teatr, „Kurier Stanisławowski” 1934, nr 946, 9 XII, s. 3.
} 
Podobnie w superlatywach wypowiadano się niej, recenzując przedstawienie Lisistrata Heinricha Bolten-Baeckersa: ,pełna ognia i temperamentu była p. Ładosiówna i czarowała nas jak zwykle bogatą skałą swego kunsztu aktorskiego" ${ }^{37}$. Drugą premierą w sezonie 1934/1935 była komedia Kiedrzyńskiego Ten i tamten, o której wystawieniu można było przeczytać między innymi: „Z pań po staremu laury i oklaski zasłużone rzetelnie zbierała przede wszystkim p. Ładosiówna (Natalia)"38.

$\mathrm{Na}$ święto Konstytucji 3 maja Teatr im. Moniuszki wystawił czteroaktową sztukę pt. Hajduczek, która była przeróbką powieści Henryka Sienkiewicza Pan Wołodyjowski, dokonaną przez Leona Popławskiego. Opinia krytyka „Kuriera Stanisławowskiego” była pozytywna: „Wykonanie pod kierownictwem reżyserskim p. Ładosiówny zadowoliło w zupełności widownię"39. Pochwaleni zostali także wykonawcy głównych ról.

Pod koniec sezonu Ładosiówna zaprezentowała jako reżyser komedię Daria Niccodemiego Cień i kolejny raz zebrała pochwały w prasie: „reżyseria p. Ładosiówny pokazała rzecz opracowaną w każdym szczególe sumiennie i z nakładem prawdziwie rzetelnego wysiłku artystycznego" ${ }^{40}$. Grała też w komedii Anny Balińskiej Szczęście od jutra, w której, zdaniem rezenzenta, „Najwięcej laurów zbierała zasłużenie p. Ładosiówna, wykonawczyni głównej i milutkiej zresztą roli" ${ }^{41}$.

Na początku 1935 roku Zuzanna Łozińska, dyrektor Teatru im. St. Moniuszki, podzieliła zespół teatralny: grupa „A” pod dyrekcją Łozińskiej jeździła z przedstawieniami po województwie stanisławowskim, od czasu do czasu wystawiając na scenie teatru w Stanisławowie premiery. Zadaniem grupy „B” były wyjazdy do miast i miasteczek województw tarnopolskiego i później lwowskiego. Kierownikiem grupy objazdowej został Zabielski. Trupy miały do dyspozycji przyznane przez Ministerstwo Komunikacji do wyłącznego użytku dwa wagony osobowe III klasy. Wagony w porze zimowej zaopatrzone były w piece węglowe. Pełniły one w ciągu całego roku, z parodniowymi przerwami, funkcję „,hotelu na kołach”, jak objaśniała Ładosiówna ${ }^{42}$.

W 1935 roku Teatr im. St. Moniuszki rzadziej gościł w Stanisławowie, gdyż jego dyrekcja, walcząca z bardzo słabą frekwencją na spektaklach, postanowiła ratować sytuację wystawianiem sztuk poza Stanisławowem. W prze-

37 Teatr, „Kurier Stanisławowski” 1935, nr 952, 6 I, s. 4.

38 Teatr, „Kurier Stanisławowski”, (j.z.), ,,Ten i tamten” komedia Kiedrzyńskiego, „,Kurier Stanisławowski” 1935, nr 990, 22 IX, s. 2.

39 J.Z., „Hajduczek” sztuka w 4 aktach wedle H. Sienkiewicza, „Kurier Stanisławowski” 1935 , nr 979, 12 V, s. 6.

40 Teatr, „Kurier Stanisławowski 1935, nr 968, 28 IV, s. 3.

41 J.Z., ,,Szczęście od jutra” komedia St. Kiedrzyńskiego, „Kurier Stanisławowski” 1935, nr 972, 19 V, s. 2.

42 Teatr Małopolski pod dyrekcją Z. Łozińskiej, PRO ARTE, Stanisławów 1938, s. 6. 
rwach pomiędzy premierami zespół pod nazwą Teatr Pokucko-Podolski objeżdżał wszystkie ważniejsze ośrodki prowincjonalne, w których miał o wiele wdzięczniejszych i liczniejszych widzów. Niestety, nie zachowały się informacje o występach poza Stanisławowem, w małych miasteczkach nie wychodziła prasa, nie było recenzentów teatralnych, nie ma zatem wiedzy na ten temat. Pozostały tylko felietony Ładosiówny, które drukowała w „Kurierze Stanisławowskim", a w których opisywała przygody teatru podczas wyjazdów do województw tarnopolskiego i stanisławowskiego. Najpierw jednak przedstawiła czytelnikom prozaiczną przyczynę powstania „teatru wędrownego":

Nie każdy, nawet z największych sympatyków teatralnych wie, jak wyglądał koniec zimowego sezonu w Teatrze Moniuszki. A kto wie, czy taki „widoczek” nie zainteresowałby wszystkich tych, którzy byli wiernymi przyjacielami naszymi i stałymi bywalcami Stanisławowskiego Domu Sztuki. - Dla nich więc poświęcony będzie dzisiejszy felieton, wraz z pozdrowieniami od garstki aktorów, rozwożących imię stanisławowskiego „Podolsko-Pokuckiego” Teatru na wschodnich krańcach kraju. Było to tak, jak w jakiej bajce: „zawitał maj - zakwitly bzy... i w kasie teatralnej zrobiło się cicho, a na sali widzów, coraz więcej ... świeżego powietrza - czyli z kwiatów bzu i śpiewu słowika zrodził się sezon ... ogórkowy. Ale energiczny dyrektor w spódnicy - to jest, nie - przepraszam - chciałam powiedzieć, w uroczej sukieneczce - rozkazał: „pakować manatki - dzielić zespół na dwie „grupy” (,A” i „B”) i dalej na prowincję! $!^{43}$.

Planowano, że w następnym sezonie obie grupy będą stale w drodze, przerywając objazd jedynie na dwa lub trzy dni w miesiącu, by przyjechać do Stanisławowa w celu zmiany zespołu, kostiumów, dekoracji itd. Właśnie w takim wagonie (trzeciej klasy) „obóz” Moniuszkowców wyruszył w swoje objazdy, dając przedstawienia w Dolinie, Podhajcach, Podwysokiem, Brzeżanach i innych miejscowościach.

Prowincja przyjmuje ,grupę Be” serdecznością moralną i materialnym... jak się uda - komentowała przedsięwzięcie Ładosiówna. - Żałoba państwowa wpłynęła ujemnie na frekwencję teatralną, bo nie wszyscy rozumieją, że teatr jest placówką kulturalno-oświatową - duchową strawą każdego myślącego i czującego człowieka - a nie tylko rozrywką, nie licującą z powagą chwili. - Ale jest także i publiczność, dla której gra się z całą satysfakcją - fluid zrozumienia i reagowania płynie wówczas z widowni ku scenie, dodając artystycznego bodźca wykonawcom, a ciepło braw płaci za mękę pracy, naprawdę, w niezwykle ciężkich warunkach. [...] Najmilszem jednak zadośćuczynieniem jest obcowanie z przyrodą i poznawanie miast i miasteczek - ich upodobań i charakterów. Pachnąca zielenią, artystyczna Dolina serdecznie wyciąga ręce po „Grupę Be” już z daleka; W drodze do Podhajec pozdrawia nas prastary, piękny krzyż przydrożny w Podwysokiem, stojący twardo na czterech nogach pogańskiego jeszcze Światowida. Skupione

43 I. Ładosiówna, List z pałacu na kółkach, „Kurier Stanisławowski” 1935, nr 977, 23 VI, s. 2-3. 
Brzeżany drzemią znużone rechotaniem żab, a rozkajakowana Kamionka Strumiłowa śmieje się w blaskach pięknego dnia lśniącą wstęgą Bugu. A te nocne powroty do ,pałacu na kółkach”- pełne mrugania gwiazd i słowiczych treli ${ }^{44}$.

Z felietonów Ładosiówny można się dowiedzieć, że objazdowa grupa Teatru Pokucko-Podolskiego w lipcu i czerwcu dawała przedstawienia w Trembowli ${ }^{45}$. Później wyruszyła do Zaleszczyk ${ }^{46}$, stąd do Husiatyna i Skałatu, w końcu do Podwołoczysk, które sprawiły na aktorach ponure wrażenie:

Szary, długi budynek stacyjny wśród okropnych zabudowań miasteczka - przypomina spłowiałą, balową suknię babuni, z paradą w graciarni strychowych wspomnień. Wszystko to... było - dziś martwota i cisza, nieprzerywana nawet echem dawnej świetności. Oto hale celne, ongiś zgiełkliwe i pełne ludzi, w których teraz drzemią zawieszone u szczytu nietoperze, peron rozległy, wygodny i nad nim rozpięta korona liter o utraconym blasku: „Podwołoczyska”"

W tej miejscowości aktorzy Teatru Pokucko-Podolskiego mieli możliwość zobaczyć ówczesną granicę Polski, gdyż uprzejmy oficer KOP-u zaprowadził ich, po załatwieniu specjalnych przepustek, tam, gdzie

groźne napisy zabraniają wszelkich spacerów i oznajmiają dobitnie: „300 metrów do Granicy Państwa". Wkraczamy na te trzysta metrów i przemierzamy je szybkim, nieco nerwowym krokiem. - Już tylko $300 \mathrm{~m}$ Polski! - czy to nie brzmi dziwnie $300 \mathrm{~m}$ Polski, ciągnącej się wysoko usypanym półwyspem, wchodzącym ostrym klinem w łąki i Zbrucz - w tym miejscu czysto sowieckim - identycznie zachowana granica dawnej Austrii. Półwysep kończy się mostem, już nie naszym, przed którym zamyka drogę taki najzwyczajniejszy na świecie, po polsku zwany „szlaban" - a przed nim i za - dwa słupy graniczne i dwie budki wartowników: biało-czerwona - polska i czerwono-zielona - sowiecka. [...] Jeszcze jedno tęskno-ciekawe spójrzenie w dal i żegnamy krajobrazy słowami z roli: „Praszczaj Rasija! - Praszczaj Towariszcz! ${ }^{48}$.

Irena Ładosiówna opisała warunki pracy aktorów grupy objazdowej Teatru Pokucko-Podolskiego, która podróżowała wagonem opatrzonym ,pięknym numerem" 18-785 po dwóch województwach wschodnich:

Jakieś pół cygańskie, pół cyrkowe piętno zawisło nad całością: pasiaste kilimki, wzorzyste portiery i firanki - typowe urządzenie legendarnego, wędrownego teatru, znanego współczesności tylko z opisów, który się tak dawno przeżył, że aż... zmartwychwstał na nowo. Imię jego powinno być znane i miłe dla każde-

44 Ibidem, s. 3.

45 I. Ładosiówna, Stanisławowski Teatr w „Podolskich Jarach”. Specjalna korespondencja dla „, Kuriera Stanisławowskiego”, „Kurier Stanisławowski” 1935, nr 980, 14 VII, s. 2-3.

46 Eadem, $W$ polskim Meranie, „Kurier Stanisławowski” 1935, nr 984, 11 VIII, s. 2.

47 Eadem, Tam gdzie się Polska kończy, „Kurier Stanisławowski” 1935, nr 989, 15 IX, s. 2.

48 Ibidem. 
go Stanisławowianina: „Teatr Pokucko-Podolski”! Jeździ sobie teraz ta „bida” ze sztuczkami Pan Damazy (na popołudniówki) i Ten $i$ tamten (jako wieczorne widowisko) rozsławiając imię swego rodzica (Stanisławowa) w najdalszych zakątkach Pokucia i Podola... wędrowne ptaki Melpomeny ${ }^{49}$.

Życie aktorów teatru objazdowego nie było łatwe, albowiem przedstawienia odbywały się przeważnie w zimnych salach miejscowych „Sokołów” lub klubów, ale mimo wszystkich niedogodności w tej pracy było coś pięknego - wnosiła ona coś niecodziennego i radosnego w prowincjonalną szarość i nudę. Zwłaszcza wdzięcznymi odbiorcami przedstawień teatralnych byli najmłodsi widzowie:

Ile nagrody mogą dać spojrzenia dzieci! Nagrody i prośby!... Nie grając w popołudniówce, często zastępuję kasjera i wtedy otacza mię zwarty krąg spojrzeń młodzieży: są spojrzenia gorące, pospieszne w niecierpliwości, w oczekiwaniu drgające, spojrzenia marzycielskie, powolne, snujące domysły tego, co zobaczą - spojrzenia czekające piękna [...] spojrzenia proszące, niemal żebracze tych, co nie mają na bilet i idą popatrzeć się bodaj przez szparę uchylonych drzwi na błyski tajemnicy teatralnej. Och, te spojrzenia łaszące się jak psy zgłodniałe, bezpańskie. Chciałoby się po prostu sypnąc im całą księgę biletową: macie, używajcie, cieszcie się, nie bądźcie takie głodne!!! I kiedy posiadacze znikną już w czeluściach zciemnionej sali, kasjerka zagłębia się z bijącym mocno sercem w rachunki tak bardzo, aby tylko nie widzieć wkradających się cichcem „złodziei śmiechu i radości”, ${ }^{\prime 50}$.

Irena Ładosiówna, która w swoim stanisławowskim okresie życia współpracowała z „Kurierem Stanisławowskim”, wydrukowała na jego łamach około 30 felietonów oraz nowel. Najcenniejsze są te felietony, w których opisywała losy trupy teatru objazdowego podczas jej wędrówek po województwach stanisławowskim i tarnopolskim.

Prasa miejscowa donosiła o występach teatru m.in. w Tłumaczu, Kołomyi, Śniatynie oraz Zabłotowie już w $1934 \mathrm{roku}^{51}$. Z zachowanych roczników tarnopolskiej gazety „Głos Polski” można się dowiedzieć, że Teatr Pokucko-Podolski ze Stanisławowa wystawił 26 stycznia 1935 roku w Tarnopolu sztukę Devala Towariszcz:

W ubiegłą sobotę dyrekcja teatru Pokucko-Podolskiego wystawiła sztukę J. Devala pt. „Towariszcz” [...] przez parę godzin widz, od pierwszego do ostatniego słowa padającego ze sceny, był pod wrażeniem wiatru ze wschodu [...] niesposób w krótkiej recenzji opowiedzieć dokładnie całą treść sztuki i przebieg akcji,

\footnotetext{
49 I. Ładosiówna, Korespondencja wagonowa, „Kurier Stanisławowski” 1935, nr 1001, 8 XII, s. 2.

50 Ibidem.

51 Teatr, „Kurier Stanisławowski” 1934, nr 936, 4 XI, s. 4.
} 
przyznać natomiast należy, że cały szereg scen, że wszystkie wprowadzone przez autora na scenę osoby są pomyślane, przeprowadzone i przedstawione niemal po mistrzowsku [...] P. I. Ładosiówna w roli Tatiany Pietrowny była bez konkurencji [...] P. Wasilewski, jako książę Michał Aleksandrowicz Urajew [...] pokazał nam znowu wysoki stopień swej gry w całej pełni. Nadto należy mu się pełne uznanie za reżyserię sztuki trudnej i - dobrej ${ }^{52}$.

W maju 1935 roku niespodziewanie ciężko zachorował na zapalenie płuc i wkrótce zmarł aktor i reżyser, Kazimierz Kijowski. Miejscowy poeta poświęcił mu wiersz. Irena Ładosiówna pisała natomiast w „Kurierze Stanisławowskim":

Kazimierz Kijowski - odszedł od nas! - Ten który nie tak dawno wyczarował postać Boryny w „Zaczarowanym kole”, Dziennikarza w „Weselu”, Cześnika w „Zemście” - już grać więcej nie będzie, odszedł tam, skąd się już nie wraca, zostawiając po sobie wielki żal wśród wszystkich tych, którzy Go znali. [...] Był Jednym z Tych, którzy żyli tylko Sceną i dla Sceny Polskiej, ze Sztuką i dla Sztuki - mając w Swej duszy i krwi pragnienie dobra Teatru. Był Jednym z Tych którzy nie dbając o sławę, brawa i blichtr zewnętrzny mają na celu Pracę i Prawdę! Był jednym z Tych, których się żegna z całego serca serdecznym wołaniem: „Żegnaj Drogi, Kochany Kolego! - Cześć Twej Pamięci! ${ }^{53}$.

Trzeci sezon teatralny 1935/1936 teatr w Stanisławowie rozpoczął 7 września 1935 roku. Kierownikiem zespołu była, jak wcześniej, Łozińska, administratorem zaś - Faliszewski. Z ubiegłorocznego składu w zespole pozostali: Seweryn Butrym, Janina Gozdecka, Janina Hitnarowicz, Józef Klejer, Irena Ładosiówna, Stefan Posiadłowski, Maria Sieniawska, Ryszard Wasilewski, Helena Wostrowska i Wacław Zabielski. Inauguracyjnym spektaklem była komedia Stefana Żeromskiego Uciekła mi przepióreczka w reżyserii Wasilewskiego. Przedstawienie zgromadziło niewielu widzów, zapewne z tej przyczyny, że było wznowieniem sztuki z poprzedniego sezonu. W prasie odnotowano:

Czołowe postaci obsadzone bardzo szczęśliwie skupiały na sobie słusznie zainteresowanie całej widowni. Zgoła nie teatralne sylwetki, ale pulsujące pełnią prawdy życiowej kreowały panie Łozińska (Smugoniowa) i Ładosiówna (Księżniczka); [...] doskonale pracującymi partnerami obu pań byli pp. Butrym i Klejer, pierwszy w roli Smugonia, drugi docenta Przełęckiego ${ }^{54}$.

W omawianym sezonie Ładosiówna wyreżyserowała także sztuki Arletta i zielone pudła autorstwa Germaine i Alberta Acremantów i komedię Franza

\footnotetext{
52 Teatr, (wsd) „Towariszcz” komedia w 4 aktach J. Devala, „Głos Polski” 1935, nr 4, 28 I, s. 2-3.

53 I. Ładosiówna, Nad świeża mogiła, „Kurier Stanisławowski” 1935, nr 959, 5 V, s. 4.

54 J.Z., ,Uciekła mi przepióreczka” Stefana Żeromskiego, „Kurier Stanisławowski” 1935, nr 989, 15 IX, s. 5.
} 
von Schönthana Odrodzenie. Przygotowanie jej wymagało niemałej pracy, ale też pewnej dozy intuicji historycznej oraz entuzjazmu. Krytyk „Kuriera Stanisławowskiego” docenił też grę Ładosiówny: „Nasi artyści stanęli na wysokości niełatwego zadania.[...] P. Ładosiówna z właściwą sobie intuicją sprezentowała nam typ damy renesansowej, u której rwący nurt nowego życia i nowych myśli i pragnień tłumi przebrzmiałe echa średniowiecznej powagi i surowości" ${ }^{5}$.

W komentarzu „Kuriera Stanisławowskiego” chwalono jej pracę ${ }^{56}$. Także w jej reżyserskim opracowaniu wystawiono w 1936 roku komedię László Bús-Feketego To więcej niż mitość c $^{57}$ i Bernarda Shawa Pygmalion ${ }^{58}$, w której grała postać Doolittle. Wówczas w prasie znowu wysoko oceniono jej grę: „wydobyła całą skalę nowoczesnej Galatei, przemieniajacej się z surowej istoty ludzkiej w uroczą kobietę. Zwłaszcza scena wizyty u matki Higginsa, oraz końcowa scena przedostatniego aktu, zagrane były po mistrzowsku" 59 .

Z czasem w dorobku stanisławowskiego teatru przybywało sztuk wyreżyserowanych przez Ładosiównę. Wystawiony został dramat Tadeusza Rittnera $W$ małym domku, który zdaniem recenzenta „Kuriera Stanisławowskiego" został pokazany publiczności „w doskonałym jak zawsze reżyserskim opracowaniu p. Ładosiówny”. „Ujrzeliśmy na scenie - komentował dalej autor - drobny wycinek życia z jego codziennymi, szarymi jakże często małostkowymi troskami i zmartwieniami, ujrzeliśmy mały salonik małego domku w jakiejś małej mieścinie galicyjskiej”60.

W 1937 roku Ładosiówna reżyserowała komedię Adolfa Edmunda de Herza Zamieszaj, w której wystąpiła także jako aktorka i „zasłużyła sobie na wielką porcję pochwał i uznania za grę, pod każdym względem skończoną”, jak pisano w „Kurierze Stanisławowskim” ${ }^{61}$. Następnie Ładosiówna przygotowała Most Jerzego Szaniawskiego, które to przedstawienie zostało wysoko ocenione: „,całość zaliczyć należy do najlepiej udanych w bieżącym sezonie, przy czym reżyseria p. Ireny Ładosiówny była jak zawsze opracowana w najdrobniejszych szczegółach, oraz umiejętnie podkreśliła istotny sens sztuki" ${ }^{62}$. Nie mniej pochlebne było zdanie recenzenta o wystawieniu

Teatr Pokucko-Podolski pod dyr. Zuzanny Łozińskiej, „Kurier Stanisławowski” 1935, nr 994, 20 X, s. 4.

56 Z teatru, „Kurier Stanisławowski” 1935, nr 996, 27 X, s. 3.

57 J.Z., ,,To więcej niż miłość” komedia w 3 aktach Wt. Bus-Feketego, reżyseria Ireny Ladosiównej, „Kurier Stanisławowski” 1936, nr 41, 11 XI, s. 3.

58 J.Z., „Pygmalion” komedia w 4 aktach z prologiem G.B. Shawa. Reżyseria I. Ładosiówny, oprawa malarska Tenerowicza, „Kurier Stanisławowski” 1936, nr 45, 8 XI, s. 5-6.

59 Ibidem, s. 6.

60 Z teatru, „Kurier Stanisławowski” 1936, nr 14, 26 I, s. 3.

61 Teatr, „Kurier Stanisławowski” 1937, nr 58, 7 II, s. 4.

62 Teatr, „Kurier Stanisławowski” 1937, nr 60, 21 II, s. 3. 
w reżyserii Ładosiówny komedii Christine Jope-Slade i Sewella Stokesa Zloty Wieniec:

Punktem centralnym była rzecz jasna p. Ładosiówna, jej kreacja postaci praczki Bolton była w całym tego znaczeniu mistrzowską a nowy typ, jaki sprezentowała wykonawczyni, będzie należał do tych jej kreacyj, które najchlubniej świadczą o tak bardzo bogatej skali możliwości artystycznych p. Ładosiówny. Widzieliśmy na scenie wielką doprawdy artystkę, która dobrze w dodatku umie prowadzić resztę zespołu ${ }^{63}$.

Równie udana była praca Ładosiówny jako reżysera komedii Święty wiek rycerstwa Christophera Marlowe'a. Od 1937 roku ta utalentowana członkini stanisławowskiego zespołu teatralnego była już aktorką i reżyserem Teatru Ziemi Pomorskiej w Toruniu, ale w 1938 roku przybyła do miasta, z którym wcześniej związała się latami swej pracy scenicznej, na gościnne występy. Wyreżyserowała w teatrze im. Stanisława Moniuszki dramat historyczny Juliusza Słowackiego Maria Stuart i zagrała w tej sztuce tytułową rolę. W „Kurierze Stanisławowskim" można było przeczytać:

Pani Ładosiówna, to artystka o dużej skali możliwości scenicznych, o czym zresztą przekonaliśmy się nie po raz pierwszy. Na niej spoczywał cały ciężar sztuki, a rolę swoją umiejętnie wycieniowaną i zadeklamowaną (tak właśnie jak powinny być deklamowane wiersze Słowackiego) potraktowała z artystycznym umiarem i pieknym odczuciem odtworzonej kreacji [...] reżyseria sprawna i drobiazgowa ${ }^{64}$.

Teatr stanisławowski im. Moniuszki - Teatr Pokucko-Podolski - Teatr Małopolski pod dyrekcją Łozińskiej w latach 1933-1939 dał ogółem 4227 przedstawień, z tego - 1116 w Stanisławowie, a 3111 podczas objazdów po województwach: stanisławowskim, tarnopolskim i lwowskim. Zespół odwiedził 329 miast i miasteczek ${ }^{65}$ w południowo-wschodnich województwach ${ }^{66}$. Dzięki szerokiemu zasięgowi działalności objazdowej Teatr Małopolski oka-

63 „Złoty Wieniec” kom. Christiana Jope Siede i Seveli Stokes, „Kurier Stanisławowski” 1937, nr 61, 1 III, s. 6.

${ }^{64}$ J.Z., Teatr, „Maria Stuart” dramat historyczny Juliusza Stowackiego, „Kurier Stanisławowski" 1938, nr 52, 25 XII, s. 6.

${ }_{65}$ W czasach swoich objazdów Teatr Malopolski odwiedził między innymi 26 miast i miasteczek województwa tarnopolskiego: Borszczów, Brody, Brzeżany, Buczacz, Busk, Czortkow, Chorostków, Grzymałów, Husiatyn, Kamionka Strumiłowa, Kopyczyńce, Monasterzyska, Mikulince, Mielnica, Podhajce, Podwołoczyska, Przemyślany, Radziechów, Skałat, Skała, Tarnopol, Trembowla, Zaleszczyki, Zbaraż, Zborów, Złoczów [w:] Teatr Małopolski pod dyr. Z. Łozińskiej. Pro Arte, Stanisławów 1938, s. 19.

${ }_{66}$ Teatr Małopolski pod dyrekcja Zuzanny Łozińskiej. 1933-1938. Program. Sezon 19381939, Stanisławów 1939, s. 3. 
zał się największym w Polsce teatrem tego rodzaju, a jedynym o takiej jakości pracy, prowadzonej $\mathrm{w}$ trudnych warunkach, wymagających pełnego poświęcenia i samozaparcia.

Wielkie zasługi dla rozwoju tego teatru położyła Ładosiówna, której należą się słowa uznania z powodu jej talentu oraz ofiarnej pracy aktorki, reżysera, a także publicystki. Niestety, wąskie ramy artykułu nie dają możliwości pełnego przedstawienia jej różnorodnej działalności w Stanisławowie. Niniejszy krótki szkic jest tylko namiastką pełnego obrazu tej barwnej i znaczącej postaci, która na zawsze zapisała się w dziejach polskiego teatru w Stanisławowie.

\section{BIBLIOGRAFIA}

Archiwum, Iwano-Frankiwsk. f. 2, op. 1, spr. 1249.

J.Z. 1934. Z teatru. „,Kredowe koło” Klabunda. „Kurier Stanisławowski” nr 877 (4 IV): 4.

J.Z. 1935. Teatr. ,Hajduczek” sztuka w 4 aktach wedle H. Sienkiewicza. „Kurier Stanisławowski" nr 979 (12 V): 6.

J.Z. 1935. Teatr. ,,Szczęście od jutra” komedia St. Kiedrzyńskiego. „Kurier Stanisławowski" nr 972 (19 V): 2.

J.Z. 1935. „Ten i tamten” komedia Kiedrzyńskiego. „Kurier Stanisławowski” nr 990 (22 IX): 2

J.Z. 1935. Z teatru. „Uciekła mi przepióreczka” Stefana Żeromskiego. „Kurier Stanisławowski" nr 989 (15 IX): 5.

J.Z. 1936. Z teatru. „Pygmalion” komedia w 4 aktach z prologiem G.B. Shawa. Reżyseria I. Ładosiówny, oprawa malarska Tenerowicza. „Kurier Stanisławowski” nr 45 (8 XI): 5-6.

J.Z. 1936. Z teatru. „, To więcej niż miłość” komedia w 3 aktach Wt. Bus-Feketego, reżyseria Ireny Ładosiównej. „Kurier Stanisławowski” nr 41 (11 XI): 3.

J.Z. 1938. Teatr. ,Maria Stuart” dramat historyczny Juliusza Stowackiego. „Kurier Stanisławowski" nr 52 (25 XII): 6.

Kronika. 1934. „Kurier Stanisławowski” nr 850 (31 XII): 3.

Kronika. 1934. „Kurier Stanisławowski” nr 852 (7 I): 3.

Kronika. 1934. „Kurier Stanisławowski” nr 870 (11 XII): 3.

Ładosiówna Irena. 1931. Miłość wśród maków. „Kurier Lwowski” nr 259-261; 264-268; $271-275$; 278-282; 285-289; 293; 295-296; 299-302; 306-307; 309-310; 314-317; $320-324 ; 327-331$.

Ładosiówna Irena. 1933. Gdy się Chrystus rodzi. „Kurier Stanisławowski” nr 849 (24 XII): 4-5.

Ładosiówna Irena. 1933. Przed premiera „Mademoiselle”. „Kurier Stanisławowski” nr 842 (29 XI): 2.

Ładosiówna Irena. 1934. ,Wino - dancing”- poczatek o ósmej godzinie - i „,Kobieta”w Borszczowie. „Kurier Stanisławowski” nr 896 (17 VI): 2-3.

Ładosiówna Irena. 1934. Dwie Wigilie. „Kurier Stanisławowski” nr 950 (23 XII): 2-3.

Ładosiówna Irena. 1934. Majowe brednie. „Kurier Stanisławowski” nr 885 (6 V): 4.

Ładosiówna Irena. 1934. Nocna próba (Ze wspomnień o Lwowskim Teatrze). „Kurier Stanisławowski” nr 880 (18 IV): 2. 
Ładosiówna Irena. 1934. O brzozach, na których zakwitty wiśnie. Moim kochanym Pomocnikom, na pamiatke premiery „,Kredowego Koła”. „Kurier Stanisławowski” nr 876 (1 IV): 4-5.

Ładosiówna Irena. 1934. O kwiecie paproci (List z Olesiowa). „Kurier Stanisławowski” nr 900 (1 VII): 2.

Ładosiówna Irena. 1934. O zgubie świętego Marcina. „Kurier Stanisławowski” nr 947 (9 XII): 2.

Ładosiówna Irena. 1934. Pająk na sieci. „Kurier Stanisławowski” nr 916 (26 VIII): 4.

Ładosiówna Irena. 1934. Pamiętnik zadusznej świecy. „Kurier Stanisławowski” nr 935 (31 X): 2-3.

Ładosiówna Irena. 1934. Panem et circenses!. „Kurier Stanisławowski” nr 890 (27 V): 4-5. Ładosiówna Irena. 1934. Robot i kobieta. „Kurier Stanisławowski” nr 898 (24 VI): 2-3.

Ładosiówna Irena. 1934. Wielki festyn na powodzian. „Kurier Stanisławowski” nr 912 (12 VIII): 4-5.

Ładosiówna Irena. 1935. Bajka Zaduszna (Z podań Tarnopolszczyzny). „Kurier Stanisławowski" nr 996 (3 XI): 2.

Ładosiówna Irena. 1935. Korespondencja wagonowa. „Kurier Stanisławowski” nr 1001 (8 XII): 2.

Ładosiówna Irena. 1935. List z pałacu na kółkach. „Kurier Stanisławowski” nr 977 (23VI): 2-3.

Ładosiówna Irena. 1935. Nad świeżą mogiła. „Kurier Stanisławowski” nr 959 (5 V): 4.

Ładosiówna Irena. 1935. Stanisławowski Teatr w „Podolskich Jarach”. Specjalna korespondencja dla „Kuriera Stanisławowskiego”. „Kurier Stanisławowski” nr 980 (14 VII): 2-3.

Ładosiówna Irena. 1935. Tam gdzie się Polska kończy.... „Kurier Stanisławowski” nr 989 (15 IX): 2.

Ładosiówna Irena. 1935. W polskim Meranie. „Kurier Stanisławowski” nr 984 (11 VIII): 2.

Ładosiówna Irena. 1936. Opowieść zimowa. (Moim kochanym Uczenicom - na gwiazdkę). „Kurier Stanisławowski” nr 1005 (5 I): 2-3.

Ładosiówna Irena. 1936. Śmierć wagonu. „Kurier Stanisławowski” nr 9 (1 III): 2.

Stownik biograficzny teatru polskiego 1900-1980. 1994. T. II. Warszawa: Instytut Sztuki PAN.

Teatr Małopolski pod dyr. Z. Łozińskiej. Pro Arte. 1938. Stanisławów.

Teatr Małopolski pod dyrekcja Zuzanny Łozińskiej. 1933-1938. Program. Sezon 19381939. 1939. Stanisławów.

Teatr Pokucko-Podolski pod dyr. Zuzanny Łozińskiej. 1935. „Kurier Stanisławowski” nr 994 (20 X): 4.

Teatr. ,Złoty Wieniec” kom. Christiana Jope Siede i Seveli Stokes, 1937 „Kurier Stanisławowski", nr 61, 1 III, s. 6.

Teatr. 1933 „Kurier Stanislawowski” nr 832 (25 X): 30.

Teatr. 1933. „Kurier Stanisławowski” nr 830 (18 X): 2.

Teatr. 1934. „Kurier Stanisławowski nr 867 (25 II): 3.

Teatr. 1934. „Kurier Stanisławowski” nr 931 (17 X): 4.

Teatr. 1934. „Kurier Stanisławowski” nr 915 (5 IX): 3.

Teatr. 1934. „Kurier Stanisławowski” nr 923 (19 IX): 4.

Teatr. 1934. „Kurier Stanisławowski” nr 933 (24 X): 3.

Teatr. 1934. „Kurier Stanisławowski” nr 937 (7 XI): 2.

Teatr. 1934. „Kurier Stanisławowski” nr 834 (1 XI): 3.

Teatr. 1934. „Kurier Stanisławowski” nr 836 (12 XI): 3. 
Teatr. 1934. „Kurier Stanisławowski” nr 842 (29 XI): 4.

Teatr. 1934. „Kurier Stanisławowski” nr 845 )10 XII): 4.

Teatr. 1934. „Kurier Stanisławowski” nr 852 (7 I): 3.

Teatr. 1934. „Kurier Stanisławowski” nr 866 (25 II): 5.

Teatr. 1934. „Kurier Stanisławowski” nr 873 (21 III): 3.

Teatr. 1934. „Kurier Stanisławowski” nr 878 (14 IV): 3.

Teatr. 1934. „Kurier Stanisławowski” nr 885 (6 V): 3.

Teatr. 1934. „Kurier Stanisławowski” nr 891 (30 V): 3.

Teatr. 1934. „Kurier Stanisławowski” nr 892 (31 V): 4.

Teatr. 1934. „Kurier Stanisławowski” nr 936 (4 XI): 4.

Teatr. 1934. „Kurier Stanisławowski” nr 938 (11 XI): 5.

Teatr. 1934. „Kurier Stanisławowski” nr 946 (9 XII): 3.

Teatr. 1935. „Kurier Stanisławowski nr 968 (28 IV): 3.

Teatr. 1935. „Kurier Stanisławowski” nr 952 (6 I): 4.

Teatr. 1937. „Kurier Stanisławowski” nr 58 (7 II): 4.

Teatr. 1937. „Kurier Stanisławowski” nr 60 (21 II): 3.

Teatr. 1937. „Kurier Stanisławowski” nr 14 (5 IV): 4.

wsd. 1935. Teatr. „Towariszcz” komedia w 4 aktach J. Devala. „Głos Polski” nr 4 (28 I): 2-3.

Z teatru. 1935. „Kurier Stanisławowski” nr 996 (27 X): 3.

Z teatru. 1936. „Kurier Stanisławowski” nr 14 (26 I): 3.

Ziobrowski Leon. 1933. Stały zawodowy teatr w Stanisławowie. „Kurier Stanisławowski” nr 818 (6 VIII): 2.

\section{IRENA ŁADOSIÓWNA - ACTRESS OF POLISH THEATRE IN STANISŁAWÓW AND JOURNALIST OF “STANISŁAWÓW COURIER” (1933-1936)}

Summary. The article is devoted to the theatrical career of Irena Ladosiówna, actress and director, during her stint on the stage of the Stanisław Moniuszko Polish Theatre in Stanisławów in 1933-1937, where she was successful as a versatile actress playing a wide variety of roles, as well a director responsible for entire productions. Moreover, Miss Ładoś is presented here also as a columnist for The Stanisławów Courier. Her profile is based on press articles concerning the Stanisławów theatre in 1933-1937 and her own columns from the period.

Key words: Irena Ładosiówna, theatre, actress, director, journalist

\section{ІРЕНА ЛАДОСЬ - АКТРИСА ПОЛЬСЬКОГО ТЕАТРУ В СТАНІСЛАВОВІ ТА ЖУРНАЛІСТКА “СТАНІСЛАВСЬКОГО КУР’СРА” (1933-1936)}

Резюме. Дана стаття присвячена спробі висвітлення художньої діяльності Ірени Ладось, акторки та режисера. Увага автора статті зосередженя на період 1933-1937, коли польська актриса працювала на сцені Польського театру ім. Станіслава Монюшка в Станіславові, в якому не тільки успішно виконувала різці сценічні ролі, а також виправдалась як режисер, відповідальний за концепцію та підготовку теа- 
тральної вистави. Крім того стаття представляє Ірену Ладось як автора фейлетонів, що друкувались у тодішньому “Станіславському кур’єрі” („Kurier Stanisławowski”). Основним джерелом інформації авторка використовує статті, що торкаються діяльності Станіславівського театру, а також фейлетони І. Ладось з 1933-1936 рр.

Ключові слова: Ірена Ладось, театр, актриса, режисер, журналістка 